\title{
Upaya Internalisasi Nilai-Nilai Budaya Peumulia Jamee Masyarakat Aceh dalam Pembelajaran Sejarah (Studi Kasus di SMA Negeri 1 Darul Makmur)
}

\author{
Chaerol Riezal $^{(1)}$, Hermanu Joebagio $^{(2)}$, Susanto $^{(3)}$ \\ ${ }^{1}$ Mahasiswa Magister Pendidikan Sejarah, Universitas Sebelas Maret, Surakarta \\ ${ }^{2}$ Guru Besar Pendidikan Sejarah, Universitas Sebelas Maret, Surakarta, Indonesia \\ ${ }^{3}$ Dokor Ilmu Sejarah, Universitas Sebelas Maret, Surakarta, Indonesia \\ Email: ${ }^{1}$ chaerolriezal@gmail.com, ${ }^{2}$ hermanu.joebagio@staff.uns.ac.id \\ ${ }^{3}$ sussastra@gmail.com
}

\begin{tabular}{l}
\hline Tersedia Online di \\
\hline http://www.jurnal.unublitar.ac.id/ \\
index.php/briliant
\end{tabular}

\section{Sejarah Artikel}

Diterima pada 3 April 2018

Disetuji pada 29 April 2018

Dipublikasikan pada 13 Mei 2018

Hal. 190-200

\section{Kata Kunci: \\ internalisasi, peumulia jamee, nilai budaya, masyarakat aceh, pembelajaran sejarah}

\section{DOI:}

http://dx.doi.org/10.28926/briliant .v3i2.167

\begin{abstract}
Abstrak: Penelitian ini bertujuan untuk menanamkan nilai-nilai budaya Peumulia Jamee masyarakat Aceh kepada siswa dan siswi di SMA Negeri 1 Darul Makmur melalui pembelajaran sejarah, dimana dalam budaya tersebut terkandung nilai-nilai yang terkait dengan agama dan sosial. Bentuk penelitian ini adalah kualitatif deskriptif. Teknik pengumpulan data dilakukan dengan cara observasi, wawancara, serta mengkaji dokumen dan arsip pembelajaran. Hasil penelitian ini yaitu (1) Mendeskripsikan pemahaman guru tentang nilainilai budaya Peumulia Jamee, (2) Mendeskripsikan internalisasi nilai-nilai budaya Peumulia Jamee dalam pembelajaran sejarah, (3) Mendeskripsikan kendala-kendala yang dihadapi guru sejarah dalam internalisasi nilai-nilai budaya Peumulia Jamee dalam pembelajaran sejarah di SMA Negeri 1 Darul Makmur.
\end{abstract}

Pendidikan adalah suatu proses dalam rangka mempengaruhi peserta didik supaya mampu menyesuaikan diri dengan lingkungannya, dan dengan demikian akan menimbulkan perubahan dalam dirinya yang dapat memungkinkannya untuk berfungsi secara adekwat dalam kehidupan masyarakat (Hamalik, 2008: 3). Dalam Undang-Undang Sistem Pendidikan Nasional, pendidikan dikatakan adalah usaha sadar dan terencana untuk mewujudkan suasana belajar dan proses pembelajaran agar peserta didik secara aktif mengembangkan potensi dirinya untuk memiliki kekuatan spiritual keagamaan, pengendalian diri, kepribadian, kecerdasan, akhlak mulia serta keterampilan yang diperlukan dirinya, masyarakat, bangsa dan negara (Pasal 1, UU Sisdiknas Nomor 20/2003).

UU Sisdiknas juga mengamanatkan kompetensi lulusan yang menyangkut pengetahuan, keterampilan, dan sikap yang dirumuskan berdasarkan kebutuhan pada tingkat individu, masyarakat, bangsa dan negara, serta peradaban tuntutan globalisasi yang menuntut agar semua mata pelajaran harus berkontribusi terhadap pembentukan sikap, keterampilan, pengetahuan dan pemahaman jauh lebih baik dimengerti melalui pendekatan pengetahuan multi disiplin (Suradi, 2017: 522). 
Dalam masa pembangunan bangsa, salah satu fungsi utama pendidikan adalah pengembangan kesadaran nasional sebagai sumber daya mental dalam proses pembangunan kepribadian nasional serta identitasnya (Kartodirdjo, 1993). Hal itu kembali diperkuat oleh UU Sisdiknas yang menjelaskan bahwa pendidikan nasional berfungsi mengembangkan kemampuan dan memberikan watak serta peradaban bangsa yang bermartabat dalam rangka mencerdaskan kehidupan bangsa, bertujuan untuk mengembangkan potensi peserta didik agar menjadi manusia yang beriman, bertaqwa kepada Tuhan Yang Maha Esa, berakhlak mulia, sehat, berilmu, cakap, kreatif, mandiri, menjadi warga negara yang demokratis dan bertanggung jawab (Pasal 3, UU Sisdiknas Nomor 20/2003).

Selain menyatakan fungsi dan tujuan pendidikan nasional, pendidikan berbasis kebudayaan juga tertuang dalam undang-undang tersebut. Pada bab I pasal 1 UU Sisdiknas, dikatakan bahwa pendidikan berbasis masyarakat adalah penyelenggaraan pendidikan yang berdasarkan kekhasan agama, sosial, budaya, aspirasi, dan potensi masyarakat sebagai perwujudan pendidikan dari, oleh, dan untuk masyarakat. Maka, salah satu problem di era globalisasi adalah bagaimana membangun karakter masyarakat melalui pendidikan, baik pendidikan formal maupun non fomal khususnya melalui nilai-nilai kearifan lokal (Rasyid, 2015: 56). Oleh karena itu, pendidikan berbasis budaya lokal dipandang sebagai solusi cerdas untuk menghasilkan peserta didik yang memiliki kepribadian unggul dan menjunjung tinggi nilai-nilai kebudayaan secara menyeluruh. Tujuannya adalah untuk membentengi generasi bangsa Indonesai dari gemburan arus globalisasi dan pertukuran kebudayaan yang sedang melanda dunia saat ini.

Nadlir (2014: 310) mengatakan bahwa pendidikan berbasis kearifan lokal adalah pendidikan yang lebih didasarkan kepada pengayaan nilai-nilai kultural serta memanfaatkan keunggulan lokal dan global dalam aspek ekonomi, seni budaya, SDM, bahasa, teknologi informasi dan komunikasi, ekologi, dan lain-lain ke dalam kurikulum sekolah yang akhirnya bermanfaat bagi pengembangan kompetensi peserta didik yang dapat dimanfaatkan untuk persaingan global. Karena itulah, pendidikan berbasis kearifan lokal semakin terasa krusial ditengah keragaman bangsa dan arus globalisasi saat ini.

Sekolah Menengah Atas (SMA) merupakan titik balik bagi peserta didik sebelum melangkah untuk menjalani kehidupan sosial di masyarakat. Oleh karena itu, perlu adanya penanaman terhadap nilai-nilai budaya lokal dalam pembelajaran sebagai dasar untuk mempertahankan dan melestarikan budaya kepada peserta didik. Nilai-nilai yang terkandung dalam budaya lokal dapat di internalisasi dalam pembelajaran, salah satunya adalah pembelajaran sejarah. Internalisasi nilai-nilai budaya dalam pembelajaran sejarah dapat mempermudah proses internalisasi nilai oleh peserta didik. Hal ini di dasarkan pada pemikiran bahwa peserta didik secara langsung akan semakin terbiasa dengan nilai-nilai budaya yang diberikan dalam pembelajaran sejarah, sehingga peserta didik juga akan semakin terbiasa untuk memiliki kesadaran berpikir akan pentingnya budaya sebagai identitas daerah.

Salah satu budaya lokal yang dapat diinternalisasi ke dalam pembelajaran sejarah adalah budaya Peumulia Jamee yang dimiliki oleh masyarakat Aceh. Budaya Peumulia Jamee merupakan cara masyarakat Aceh dalam menyambut dan memuliakan tamu, baik melalui makanan khas daerah, upacara agama dan sosial maupun pertunjukan seni tari. Budaya Peumulia Jamee merupakan bukti kuat bahwa masyarakat Aceh adalah orang-orang yang sangat terbuka dan mudah 
menerima kehadiran tamu dari dalam dan luar Aceh. Dibalik karakteristik orang Aceh yang dikenal keras, namun memiliki keramahan dalam menerima tamu. Oleh karena itu, budaya Peumulia Jamee perlu dipertahankan dan dilestarikan kepada generasi muda, karena di dalamnya terkandung nilai-nilai yang terkait dengan agama Islam, adat, sosial, dan kemanusiaan.

Mengingat begitu pentingnya nilai-nilai yang terkandung dalam budaya Peumulia Jamee Aceh, maka perlu diinternalisasi kepada peserta didik melalui pembelajaran sejarah di SMA sebagai sarana untuk menumbuhkan kecintaan siswa terhadap budaya Aceh agar terbentuk warga negara yang memiliki wawasan global, tetapi tidak melupakan tradisi-tradisi lokal sebagai dasar utama dalam menjalankan kehidupan berbangsa dan bernegara. Hal ini sesuai yang dikatakan oleh Wahab (1996: 27) bahwa warga negara yang perspektif global yang mana harus senantiasa membina warga negara Indonesia yang loyal, berdedikasi, dan bertanggung jawab dalam menghadapi persoalan bangsa dan negara sehingga warga negara senantiasa berpikir global, dan bertindak nasional.

Pembelajaran sejarah dapat mengembangkan aktivitas siswa dengan melakukan kajian terhadap budaya Peumulia Jamee masyarakat Aceh, untuk kemudian dipahami dan diinternalisasi kepada peserta didik sehingga melahirkan contoh untuk bersikap dan bertindak. Dalam budaya Peumulia Jamee terkandung nilai-nilai yang terkait dengan agama dan sosial, seperti memuliakan tamu, cinta tanah air, menghargai, menghormati, sopan santun, kebersamaan, kenyamanan, dan nasionalisme budaya. Beberapa nilai itu dapat digali dan dikembangkan dalam pembelajaran sejarah yang lebih bermakna. Untuk itu, kreativitas dari seorang guru sejarah sangat diperlukan untuk mengembangkan materi sejarah yang terinternalisasi nilai-nilai budaya Aceh tersebut. Guru sejarah yang mampu mentransformasikan nilai-nilai budaya Peumulia Jamee ke dalam pembelajaran sejarah kepada peserta didiknya, maka dapat menumbuhkan kembali kecintaan peserta didik terhadap budaya Peumulia Jamee sebagai identitas daerah Aceh.

Mata pelajaran sejarah di sekolah menengah atas memegang peranan penting dalam mengembangkan pembelajaran sejarah yang terinternalisasi dengan nilai-nilai budaya Peumulia Jamee Aceh. Tujuan utama pembelajaran sejarah ini adalah untuk menanamkan kesadaran akan posisi individu siswa, baik dalam kapasitasnya sebagai pribadi maupun sebagai anggota komunitas. Pembelajaran ini sangat penting dan bersifat strategis, terutama berkaitan dengan nilai-nilai budaya Peumulia Jamee. Meski demikian, pelaksanaan pembelajaran sejarah tersebut yang diterapkan di SMA Negeri 1 Darul Makmur belum maksimal untuk dirasakan dikalangan peserta didik. Hal ini dapat dilihat dari sebagian besar siswa di SMA Negeri 1 Darul Makmur, telah mengalami pergeseran nilai-nilai budaya. Oleh karena itu, perlu untuk ditingkatkan kembali pembelajaran sejarah yang terinternalisasi dengan nilai-nilai budaya Peumulia Jamee Aceh tersebut.

Pembelajaran sejarah yang terinternalisasi dengan budaya Peumulia Jamee sangat tepat digunakan sebagai media untuk menanamkan dan menguatkan kembali kecintaan dari siswa di SMA Negeri 1 Darul Makmur terhadap budaya lokal. Oleh karena itu, guru sejarah harus mampu memasukkan nilai-nilai budaya Peumulia Jamee Aceh ke dalam proses pelaksanaan pembelajaran sejarah di kelas. Pembelajaran sejarah terinternalisasi dengan nilai-nilai budaya Peumulia Jamee Aceh tentu akan berhasil apabila guru sejarah memiliki wawasan terhadap budaya Peumulia Jamee Aceh itu sendiri. Sebaliknya, guru sejarah yang kurang 
memahami makna budaya tersebut, maka cenderung kurang sensitif. Hal ini sesuai dengan pendapat Widja (1989: 23) yang mengatakan bahwa sejarah adalah mata pelajaran yang tujuannya sebagai pendidikan nilai dan moral pada akhirnya akan bermuara pada pengembangan watak atau karakter peserta didik sesuai dengan nilai-nilai, moral dan karakter Pancasila. Pendapat tersebut diperkuat oleh Kochhar (2008: 5) yang menyatakan bahwa sejarah adalah dialog antara peristiwa masa lampau dan perkembangannya ke masa depan.

Pelaksanaan penelitian ini bertujuan untuk mendeskripsikan secara lebih rinci dan mendalam mengenai internalisasi nilai-nilai budaya Peumulia Jamee Aceh dalam pembelejaran sejarah di SMA Negeri 1 Darul Makmur. Berdasarkan pada latar belakang masalah diatas yang telah diajukan oleh penulis, maka penelitian ini lebih menekankan terhadap proses dan makna internalisasi nilainilai budaya Peumulia Jamee dalam pembelajaran sejarah, sehingga akan menghasilkan data deskriptif berupa kata-kata tentang pemahaman, perencanaan, pelaksanaan, dan kendala internalisasi nilai-nilai budaya Peumulia Jamee dalam pembelajaran sejarah secara formal di SMA Negeri 1 Darul Makmur.

\section{METODE}

Penelitian ini telah dilaksanakan dari bulan Oktober sampai bulan Desember tahun 2017 di SMA Negeri 1 Darul Makmur, yang beralamat di Jalan Nasional Desa Kuta Trieng, Kecamatan Darul Makmur, Kabupaten Nagan Raya, Provinsi Aceh. Dalam penelitian ini, metode yang digunakan adalah kualitatif deskriptif dengan strategi studi kasus tunggal, karena lokasi penelitian ini hanya terdiri dari satu objek, yaitu di SMA Negeri 1 Darul Makmur. Sumber data dalam penelitian ini adalah informan, lokasi penelitian, serta dokumen dan arsip. Adapun para informan yang diwawancarai dalam penelitian ini adalah kepala sekolah, wakil kepala sekolah, guru sejarah, dan siswa di SMA Negeri 1 Darul Makmur. Teknik pengumpulan data dilakukan dengan cara observasi langsung, wawancara mendalam, serta kajian dokumen dan arsip. Teknik cuplikan (sampling) yang digunakan adalah purposive sampling. Teknik validitas data dilakukan dengan tringgulasi sumber dan trianggulasi metode. Teknik analisis data yang digunakan dalam penelitian ini adalah analisis interaktif, yang bergerak diantara tiga komponen pokok, yaitu reduksi data, sajian data, dan penarikan simpulan serta verifikasinya (Miles \& Huberman, 1984, dalam Sutopo, 2006: 113).

\section{HASIL}

Pada bagian ini, penulis menemukan temuan-temuan yang kemudian dibahas dalam pembahasan. Pembahasan terbagi dalam beberapa sub bagian yang meliputi, pemahaman guru terhadap nilai-nilai budaya Peumulia Jamee Aceh, internalisasi nilai-nilai budaya Peumulia Jamee dalam pembelajaran sejarah, dan kendala-kendala yang dihadapi guru sejarah dalam internalisasi nilai-nilai budaya Peumulia Jamee dalam pembelajaran sejarah di SMA Negeri 1 Darul Makmur.

\section{PEMBAHASAN}

Pemahaman Guru Terhadap Nilai-Nilai Budaya Peumulia Jamee Aceh di SMA Negeri 1 Darul Makmur

SMA Negeri 1 Darul Makmur merupakan salah satu lembaga pendidikan negeri yang memiliki potensi dalam menginternalisasikan nilai-nilai budaya 
Peumulia Jamee masyarakat Aceh. Hal ini tercermin dari kondisi sekolah yang sangat mementingkan hubungan guru dengan siswa dari latar belakang yang beraneka ragam dapat terjalin dengan baik. Budaya sekolah tersebut telah di kontruksi sejak lama dan berlangsung secara alami hingga sekarang.

Sebelum penulis mengkaji mengenai internalisasi nilai-nilai budaya Peumulia Jamee dalam pembelajaran sejarah di SMA Negeri 1 Darul Makmur, terlebih dahulu penulis tertarik untuk mengetahui sejauh mana pemahaman guru terhadap nilai-nilai budaya Peumulia Jamee Aceh, mulai dari kepala sekolah, wakil kepala sekolah, dan guru sejarah. Khusus guru sejarah, pemahamannya tentang nilai-nilai budaya Peumulia Jamee menjadi sangat penting, karena dalam upaya menginternalisasi nilai-nilai budaya Peumulia Jamee dalam pembelajaran sejarah, memerlukan pemahaman dari guru sejarah terhadap nilai-nilai budaya Peumulia Jamee itu sendiri sehingga dalam proses perencanaan dan pelaksanaan pembelajaran sejarah di kelas dapat berjalan lancar.

Berdasarkan hasil wawancara penulis dengan Januar, S.Pd selaku Kepala Sekolah SMA Negeri 1 Darul, mengatakan bahwa nilai-nilai yang terkandung dalam budaya Peumulia Jamee Aceh sangat penitng untuk di terapkan di setiap SMA di Kabupaten Nagan Raya, termasuk di SMA Negeri 1 Darul Makmur. Hal ini di dasarkan oleh pemahamannya bahwa di dalam budaya Peumulia Jamee Aceh itu terkandung nilai-nilai yang terkait dengan sosial dan agama Islam. Selain itu, Januar juga memandang bahwa budaya Peumulia Jamee berkaitan dengan akhlak manusia. Oleh karena itu, menjadi kewajiban bagi SMA Negeri 1 Darul Makmur untuk menjaga nilai budaya Peumulia Jamee Aceh. Beberapa nilai-nilai yang terdapat di dalam budaya Peumulia Jamee itu, sepert nilai memuliakan tamu, kenyamanan, menghargai, menghormati, ramah, sopan, santun, dan nilai agama yang bersumber dari ajaran Islam. Meski demikian, Januar juga menekankan bahwa penerapan nilai-nilai budaya Peumulia Jamee Aceh di SMA Negeri 1 Darul Makmur tidak berdiri sendiri dalam satu mata pelajaran. Menurutnya penanaman nilai-nilai budaya Peumulia Jamee dapat diintegrasikan ke dalam 8 mata pelajaran yang relevan, seperti Pkn, Bahasa Indonesia, Bahasa Inggris, Penjaskes, Sosiologi, Sejarah, Antropologi, serta Seni dan Budaya (Wawancara: Januar, 20 November 2017).

George Herisusanto yang menjabat sebagai wakil kepala sekolah bidang kurikulum mengatakan bahwa salah satu wujud dari nilai-nilai budaya Peumulia Jamee dalam lingkungan sekolah adalah adanya sikap yang saling menghargai di antara sesama siswa dan sikap memuliakan terhadap gurunya. Hal itu tercermin dari aktifitas dan kehidupan di lingkungan sekolah. Adapun strategi yang di lakukan oleh SMA Negeri 1 Darul Makmur dalam penanaman nilai-nilai budaya Peumulia Jamee kepada siswanya adalah dengan cara memberikan contoh teladan yang baik dan bagus kepada seluruh siswa dan siswi. Selain itu, di sekolah ini juga terdapat sebuh grup Tari Ranup Lampuan, yang merupakan bagian dari budaya Peumulia Jamee Aceh. Grup tari tersebut di isi oleh perwakilan siswi kelas X dan XI, serta sering di pentaskan dalam berbagai acara di Kabupaten Nagan Raya, Aceh (Wawancara: George Herisusanto, 13 November 2017).

Sundari selaku wakil kepala sekolah di bidang humas, memahami nilainilai budaya Peumulia Jamee lebih kepada hubungan sosial antara pihak sekolah dengan masyarakat sekitar di SMA Negeri 1 Darul Makmur. Menurut Sundari, nilai-nilai budaya Peumulia Jamee tidak terlepas dari hubungan sosial yang terjadi 
di antara manusia. Hal ini di dasari oleh pengertian dari budaya Peumulia Jamee itu sendiri adalah memuliakan tamu (Wawancara: Sundari, 25 November 2017).

Pendapat berbeda diungkapkan oleh Emeri Rosa Lubis selaku wakil kepala sekolah di bidang kesiswaan. Emeri Rosa Lubis memahami bahwa nilainilai yang ada di dalam budaya Peumulia Jamee Aceh tidak terlepas dari ajaran agama Islam. Aceh yang dikenal sebagai daerah yang pertama kali disinari cahaya Islam, turut mempengaruhi budaya yang ada di Aceh, termasuk budaya Peumulia Jamee. Oleh karena itu, nilai-nilai dalam budaya Peumulia Jamee Aceh sangat erat kaitannya dengan Islam, seperti nilai menghargai, menghormati, peduli, kebersamaan, sopan dan santun. Emeri Rosa Lubis juga mengatakan bahwa budaya Peumulia Jamee sangat penting untuk ditanamkan kepada siswa dan siswi di SMA Negeri 1 Darul Makmur, karena nilai budaya itu ada kaitannya dengan visi dan misi sekolah, yaitu untuk meningkatkan keimanan dan ketaqwaan kepada Allah serta mendidik siswa agar berakhlak mulia dan berilmu pengetahuan (Wawancara: Emeri Rosa Lubis, 20 November 2017).

Sementara itu, berkaitan dengan fungsi dan peranan dari budaya nilainilai Peumulia Jamee tersebut, Nasrul selaku wakil kepala sekolah bidang sarana dan prasarana mengatakan bahwa nilai-nilai budaya Peumulia Jamee dapat menjadi bekal bagi siswa dalam menjalani kehidupan di masyarakat luas. Nilainilai budaya Peumulia Jamee seperti nilai kesopanan, menghargai, dan menghormati, dapat di hayati dan di amalkan oleh siswa sebelum terjun ke masyarakatnya. Oleh karena itu, nilai-nilai budaya Peumulia Jamee Aceh sangat penting di terapkan dalam pendidikan (Wawancara: Nasrul, 17 November 2017).

Pentingnya nilai-nilai budaya Peumulia Jamee Aceh juga diungkapkan oleh guru sejarah di SMA Negeri 1 Darul Makmur. Berdasarkan hasil wawancara penulis dengan Deliana Pasaribu selaku guru sejarah kelas XI/IIS 2, mengatakan bahwa budaya Peumulia Jamee lebih di tekankan kepada cara masyarakat Aceh dalam memuliakan tamunya, sehingga dalam proses budaya itu orientasinya adalah pembentukan karakter atau identitas budaya masyarakat Aceh. Menurut Deliana Pasaribu, dalam budaya memuliakan tamu orang Aceh itu terdapat nilainilai kemanusiaan dan harmonisasi antara tuan rumah dan tamu sebagai pihak yang di muliakan. Dalam kaitannya dengan pendidikan, khusus dalam pembelajaran sejarah, tentu saja nilai-nilai budaya itu menjadi sangat penting untuk di tanamkan kepada siswa. Selain itu, Deliana Pasaribu juga mengatakan bahwa nilai-nilai budaya Peumulia Jamee juga berkaitan dengan standar nilai moral yang di miliki oleh manusia. Misalnya, secara umum bagian dari demokrasi dengan cara menghormati dan menghargai merupakan bagian dari nilai Peumulia Jamee Aceh. Kemudian adanya kesetaraan gender, dan itu juga termasuk dalam nilai budaya Peumulia Jamee, karena kesetaraan gender tercermin dalam Tarian Ranup Lampuan sebagai bagian dari budaya Peumulia Jamee Aceh. Di sekolah ini juga mempunyai grup Tarian Ranup Lampuan yang di isi oleh perwakilan siswi kelas 1 dan 2 (Wawancara: Deliana Pasaribu, 16 November 2017).

Pemahaman yang tidak jauh berbeda tentang nilai-nilai budaya Peumulia Jamee juga diungkapkan oleh Malawati selaku guru sejarah di kelas XI/MIA 2 di SMA Negeri 1 Darul Makmur. Menurut Malawati, dalam budaya Peumulia Jamee terkandung nilai-nilai agam, sosial dan dapat mempererat tali silaturrahmi. Jika nilai-nilai budaya itu tertanam dalam diri siswa, maka dalam proses pembelajaran di kelas akan sangat bermakna. Bukan hanya itu saja, tetapi juga akan terjalin tali 
silaturrahmi antara guru dan siswa, baik didalam maupun diluar lingkungan sekolah (Wawancara: Malawati, 20 November 2017).

\section{Internalisasi Nilai-Nilai Budaya Peumulia Jamee Aceh dalam Pembelajaran Sejarah di SMA Negeri 1 Darul Makmur}

Internalisasi nilai-nilai budaya Peumulia Jamee dalam pembelajaran sejarah di SMA Negeri 1 Darul Makmur merupakan upaya guru sejarah dalam menanamkan nilai-nilai budaya Peumulia Jamee ke dalam diri siswa, sehingga hal itu dapat diterapkan oleh siswa dalam menjalani kehidupan sehari-hari dan sekaligus untuk menyikapi realitas sosial secara kultural. Internalisasi nilai-nilai budaya Peumulia Jamee Aceh lebih mudah diterapkan pada mata pelajaran sejarah, karena siswa dibekali oleh berbagai tokoh sejarah dan budaya Aceh, serta contoh teladan yang bisa menarik minar belajar siswa. Sehingga siswa dapat lebih mudah untuk memahami nilai-nilai budaya Peumulia Jamee Aceh tersebut.

Setelah melakukan perencanaan pembelajaran sejarah terinternalisasi nilai-nilai budaya Peumulia Jamee Aceh, sebagaimana yang telah disusun dalam perangkat pembelajaran silabus dan RPP, maka tahapan berikutnya yang tidak kalah pentingnya adalah melaksanakan perencanaan pembelajaran tersebut. Proses internalisasi nilai-nilai budaya Peumulia Jamee dalam pembelajaran sejarah di SMA Negeri 1 Darul Makmur memiliki ciri khas dan karakterinstik tersendiri, baik dari segi perencanaan maupun pelaksanaannya. Meski guru sejarah di SMA Negeri 1 Darul Makmur sudah melaksanakan perencanaan pembelajaran sejarah yang terinternalisasi dengan nilai-nilai budaya Peumulia Jamee Aceh, namun pelaksanaannya masih menggunakan metode diskusi dan tanya jawab.

Berpijak dari budaya Peumulia Jamee Aceh, maka penulis dapat merumuskan nilai-nilai budaya Peumulia Jamee dalam pembelajaran sejarah yang diantaranya adalah nilai agama Islam, menghormati, menghargai, memuliakan, kenyamanan, sopan dan santun, tanggung jawab, kerjasama, kejujuran, kebebasan, demokratis, tolerasi, kesabaran, dan keaktifan. Dalam menginternalisasikan nilainilai budaya Peumulia Jamee tersebut, maka guru sejarah dalam melaksanakan pembelajaran sejarah di kelas menyesuaikannya dengan Kurikulum 2013. Hal itu dapat dibuktikan dari hasil kajian dokumen yang penulis lakukan pada perangkat pembelajaran yang telah direncanakan dalam silabus dan RPP oleh guru sejarah.

Kompetensi Inti yang digunakan oleh guru sejarah di SMA Negeri 1 Darul yang tercantum dalam RPP terletak pada poin ketiga, yaitu memahami, menerapkan, dan menganalisis pengetahuan faktual, konseptua, prosedural, dan metakognitif berdasarkan rasa ingin tahunya tentang ilmu pengetahuan, teknologi, seni, budaya, dan humaniora dengan wawasan kemanusiaan, kebangsaan, kenegaraan, dan peradaban terkait penyebab fenomena dan kejadian, serta menerapkan pengetahuan prosedural pada bidang kajian yang spesifik sesuai dengan bakat dan minatnya untuk memecahkan masalah. Sementara Kompetensi Dasar pada poin 3.8 yaitu menganalisis perkembangan kehidupan masyarakat, pemerintahan, dan budaya pada masa kerajaan-kerajaan Islam di Indonesia serta menunjukkan contoh bukti-bukti yang masih berlaku pada kehidupan masyarakat Indonesia masa kini, serta pada poin 4.8 yaitu, menyajikan hasil penalaran dalam bentuk tulisan tentang nilai-nilai dan unsur budaya yang berkembang pada masa kerajaan Islam dan masih berkelanjutan dalam kehidupan bangsa Indonesia pada masa kini. 
Kompetensi Inti dan Kompetensi Dasar yang digunakan dalam RPP mata pelajaran sejarah di SMA Negeri 1 Darul Makmur memperlihatkan bahwa materi yang akan disampaikan kepada siswa dan siswi sesuai dengan upaya guru sejarah dalam menginternalisasi nilai-nilai budaya Peumulia Jamee dalam pembelajaran sejarah di SMA Negeri 1 Darul Makmur. Namun, dalam hal mengidentifikasi nilai-nilai budaya Peumulia Jamee Aceh, oleh Deliana Pasaribu maupun Malawati sendiri selaku guru sejarah mengakui bahwa nilai-nilai budaya Peumulia Jamee Aceh tidak dituliskan secara formal di dalam perangkat pembelajaran, melainkan diterapkan dalam pelaksanaan pembelajaran sejarah di kelas.

Berdasarkan pada hasil kajian dokumen yang penulis lakukan terhadap perangkat pembelajaran yang digunakan oleh guru sejarah di SMA Negeri 1 Darul Makmur, maka ditemukan data bahwa kegiatan pembelajaran yang dilaksanakan oleh guru sejarah di SMA Negeri 1 Darul Makmur dibagi ke dalam tiga tahapan kegiatan, yaitu kegiatan pendahuluan, kegiatan inti, dan kegiatan penutup.

Dalam kegiatan pendahuluan, nilai-nilai budaya Peumulia Jamee yang tampak pada diri siswa adalah nilai agama, kesopanan, memuliakan, dan tanggung jawab. Nilai agama dan kesopanan dapat di lihat pada saat siswa menghayati dan mengamalkan ajaran agama Islam. Lewat bacaan Al-Qur'an dalam kegiatan pendahuluan, siswa diharapkan dapat mengikuti proses pembelajaran yang baik dan berkah sebagai amalan ibadah dan tanggung jawab siswa kepada Sang Pencipta Alam Semesta ini. Kemudian, nilai kesopanan dan memuliakan terlihat ketika siswa membalas jawaban atas salam yang diucapkan oleh gurunya, dan mencium tangan guru sebagai sikap siswa memuliakan dan menghormati gurunya.

Dalam kegiatan inti pembelajaran sejarah di SMA Negeri 1 Darul Makmur, nilai-nilai budaya Peumulia Jamee seperti nilai keaktifan, kesopanan, kebebasan, kerjasama, demokratis, menghargai, menghormati, dan kesabaran di wujudkan dalam bentuk sikap dari siswa. Semua nilai tersebut diwujudkan oleh siswa dalam memperhatikan materi ajar yang disampaikan oleh guru sejarah. Wujud lain dari nilai tersebut yang diperlihatkan siswa ketika siswa menghargai dan menghormati perbedaan pendapat dalam diskusi kelompok yang membahas tentang kerajaan-kerajaan Islam di Indonesia dan peninggalan kebudayaan Islam yang masih ada di masa kini. Dalam diskusi kelompok, nilai kerjasama dan demokratis sangat terlihat dalam kegiatan tersebut. Sementara itu, wujud dari nilai kesopanan terlihat ketika siswa ingin menyampaikan pendapatnya, maka siswa mengangkat tangan dan menyebutkan namanya sebelum memberikan pendapat. Hal ini dilakukan oleh siswa sebagai bentuk dari apa yang telah diajarkan oleh guru sejarah sebelumnya bahwa siswa harus membudayakan mengangkat tangan dan menyebutkan nama sebelum berpendapat. Selanjutnya, nilai menghargai dan menghormati terlihat dalam sesi presentasi kelompok di depan kelas. Dalam presentasi tugas kelompok ini, baik siswa yang sedang presentasi maupun siswa lainnya terlihat saling menghargai dan menghormati. Selain itu, siswa juga di berikan kebebasan untuk sekedar bertanya, berpendapat, atau menambahkan materi diskusi kelompok tersebut. Dalam hal ini, nilai demokratis dan keaktifan siswa terlihat ketika sesi bertanya dibuka oleh siswa yang bertindak sebagai moderator diskusi. Siswa tampak aktif dalam memberikan pertanyaan dan menyampaikan pendapat, sehingga dapat di ukur banyak atau tidaknya siswa yang terlibat dalam kegiatan pembelajaran sejarah tersebut. Sementara wujud dari nilai 
kesabaran terlihat ketika siswa dari kelompok diskusi dengan sabarnya menjawab beberapa pertanyaan yang diajukan oleh siswa dari kelompok lainnya.

Sedangkan dalam kegiatan penutup, nilai-nilai budaya Peumulia Jamee yang muncul adalah nilai agama, kejujuran, dan tanggung jawab. Wujud dari nilai tanggung jawab terlihat ketika siswa mengerjakan tugas yang di berikan oleh guru sejarah. Dalam mengerjakan tugas, siswa tidak dibolehkan untuk saling kerjasama atau mencontek jawaban dari temannya. Dalam hal ini, nilai tanggung jawab dan kejujuran sudah diperlihatkan oleh siswa dalam mengemban dan mengerjakan tugas yang diberikan oleh guru. Sementara nilai agama tampak ketika siswa membalas ucapan salam penutup yang disampaikan oleh gurunya sebagai tanda bahwa proses kegiatan pembelajaran sejarah di kelas telah berakhir. Sebelum guru meninggalkan ruangan kelas, siswa sekali lagi mencium tangan gurunya sebagai tanda menghormati dan memuliakan gurunya.

\section{Kendala-Kendala Internalisasi Nilai-Nilai Budaya Peumulia Jamee dalam Pembelajaran Sejarah di SMA Negeri 1 Darul Makmur}

Pembelajaran sejarah yang terinternalisasi dengan nilai-nilai budaya Peumulia Jamee Aceh di SMA Negeri 1 Darul Makmur tidak mudah untuk di terapkan. Berdasarkan hasil observasi di lapangan dan wawancara penulis dengan guru sejarah, mengatakan bahwa proses internalisasi nilai-nilai budaya Peumulia Jamee dalam pembelajaran sejarah di SMA Negeri 1 Darul Makmur terdapat beberapa kendala yang dihadapi. Beberapa kendala yang dihadapi itu terdapat kesulitan masing-masing dan muncul baik pada tingkat perencanaan, pelaksanaan, dan komponen pendukung lainnya. Hal itu diungkapkan oleh Deliana Pasaribu dan Malawati selaku guru sejarah di SMA Negeri 1 Darul Makmur.

Beradasarkan hasil wawancara penulis dengan Malawati selaku guru sejarah di kelas XI/MIA 2, maka kendala pertama yang ditemukan adalah pada tingkat keaktifan siswa. Kendala tersebut muncul pada saat menginternalisasikan nilai-nilai budaya Peumulia Jamee dalam pembelajaran sejarah di SMA Negeri 1 Darul Makmur oleh guru sejarah. Meskipun demikian, terdapat beberapa siswa yang aktif terlibat dalam proses pembelajaran di kelas berlangsung. Namun, jika di lihat secara keseluruhan, maka tingkat keaktifan ini dapat di kategorikan cukup. Untuk mengatasi kendala ditingkat keaktifan siswa yang tergolong cukup ini, Malawati terkadang langsung menunjuk siswa untuk menyampaikan pendapatnya mengenai materi yang sedang dipelajari. Dengan demikian, siswa diharapkan agar terbiasa untuk menyampaikan pendapat dan keaktifan di ruangan kelas menjadi lebih hidup (Wawancara: Malawati, 20 November 2017).

Kendala kedua adalah mengenai tingkat kemampuan yang dimiliki oleh siswa. Dalam hal ini, berkaitan dengan tanggung jawab siswa dalam mengerjakan tugas-tugas yang diberikan oleh guru dengan batas waktu pengerjaan yang telah di tentukan, seperti tugas di kelas atau tugas pekerjaan rumah. Namun, sampai pada batas waktunya, masih ada beberapa siswa yang belum mampu mengumpulkan tugas yang diberikan oleh guru tersebut. Sehingga guru harus memberikan waktu tambahan agar siswa dapat menyelesaikan tugasnya. Maka dari itu, dapat di katakan bahwa kemampuan siswa dalam mengerjakan tugas tergolong berbedabeda, termasuk dalam menerjemahkan materi atau apa yang disampaikan oleh guru. Beberapa siswa memang memiliki kemampuan yang tinggi dan cukup, 
namun sebaliknya juga ada siswa yang memiliki tingkat keterbatasan yang rendah (Wawancara, Deliana Pasaribu, 16 November 2017).

Kendala ketiga adalah berkaitan dengan masalah waktu. Deliana Pasaribu mengatakan bahwa internalisasi nilai-nilai budaya Peumulia Jamee dalam pembelajaran sejarah harus menyesuaikan dengan kondisi waktu pembelajaran di kelas, karena setiap mata pelajaran di SMA Negeri 1 Darul Makmur, sebagaimana setiap sekolah di Indonesia pada umumnya, memiliki batas waktu mengajar atau jam pelajaran tersendiri (Wawancara: Deliana Pasaribu, 16 November 2017). Hal yang sama juga diungkapkan oleh Malawati yang mengatakan bahwa setiap mata pelajaran, termasuk mata pelajaran sejarah, di batasi oleh jam pelajaran dan juga harus menyesuaikan dengan Kurikulum 2013 sehingga pelaksanaan pembelajaran sejarah yang terinternalisasi nilai-nilai budaya Peumulia Jamee di hadapkan pada masalah kekurangan waktu. Akibatnya, proses penanaman nilai-nilai budaya Peumulia Jamee Aceh kepada diri siswa tidak berjalan maksimal (Wawancara: Malawati, 20 November 2017).

Mengenai masalah kekurangan waktu atau jam mengajar ini, penulis menemukan hal tersebut pada saat observasi berlangsung di kelas XI/MIA 2 SMA Negeri 1 Darul Makmur pada mata pelajaran sejarah wajib yang dilaksanakan oleh Malawati selaku guru mata pelajaran sejarah. Hasil observasi menunjukkan bahwa terdapat kekurangan waktu dalam proses pembelajaran sejarah di kelas tersebut. Penulis juga menemukan bahwa Malawati tidak sempat melakukan evaluasi kepada para siswanya, karena waktu yang di milikinya tidak cukup untuk melakukan evaluasi. Sehingga hal ini menjadi kendala yang di hadapi oleh guru sejarah dalam menginternalisasi nilai-nilai budaya Peumulia Jamee Aceh di SMA Negeri 1 Darul Makmur.

\section{KESIMPULAN}

Berdasarkan hasil penelitian dan pembahasan diatas, maka dapat ditarik beberapa simpulan bahwa: (1) Pemahaman guru di SMA Negeri 1 Darul Makmur terhadap nilai-nilai budaya Peumulia Jamee dipahami secara mendasar dan baik. Kepala sekolah dan guru memahami bahwa nilai-nilai budaya Peumulia Jamee penting untuk ditanamkan kepada siswa, karena terkandung nilai-nilai yang terkait dengan nilai agama, adat, budaya, moral, dan sosial, serta dapat diterapkan dalam beberapa mata pelajaran yang relevan. Wujud dari nilai-nilai budaya Peumulia Jamee dalam pembelajaran sejarah di SMA Negeri 1 Darul Makmur adalah berhubungan dengan standar nilai moral yang terdiri dari nilai demokratis, menghargai, menghormati, tanggung jawab, dan kerjasama. (2) Internalisasi nilainilai budaya Peumulia Jamee dalam pembelajaran sejarah di SMA Negeri 1 Darul Makmur dilaksanakan oleh guru sejarah melalui tiga tahap kegiatan pembelajaran, yaitu kegiatan pendahuluan, kegiatan inti, dan kegiatan penutup. Ketiga kegiatan tersebut disesuaikan dengan Kurikulum 2013 serta direncanakan dalam silabus dan RPP. (3) Proses internalisasi nilai-nilai budaya Peumulia Jamee dalam pembelajaran sejarah di SMA Negeri 1 Darul Makmur terdapat beberapa kendala yang dihadapi oleh guru sejarah, seperti rendahnya tingkat keaktifan siswa, kurangnya pemahaman siswa dalam menerjemahkan materi dan mengerjakan tugas yang diberikan guru, minimnya alokasi waktu dalam melaksanakan kegiatan pembelajaran di kelas, dan Kurikulum 2013 membutuhkan banyak tahapan dalam melaksanakan pembelajaran sejarah di kelas. Meski demikian, guru sejarah di 
SMA Negeri 1 Darul Makmur selalu berupaya untuk mengatasi setiap kendala dan mencari solusi, sehingga proses penanaman atau internalisasi nilai-nilai budaya Peumulia Jamee dalam pembelajaran sejarah kepada siswa dan siswi di SMA Negeri 1 Darul Makmur dapat berjalan sebagaimana yang diharapkan.

\section{SARAN}

Penelitian ini merupakan penelitian awal, sehingga sangat di sarankan bagi peneliti selanjutnya dapat meneliti lebih lanjut mengenai topik ini. Bagi guru, hendaknya upaya internalisasi ini lebih diperhatikan dan diupayakan tidak terbatas pada materi atau pelajaran tertentu, mengingat saat ini pemerintah sedang getol untuk menguatkan pendidikan karakter di sekolah.

\section{DAFTAR RUJUKAN}

Departemen Pendidikan Nasional. 2003. Undang-Undang Nomor 20 Tahun 2003 Tentang Sistem Pendidikan Nasional. Jakarta: Depdiknas.

Hamalik, Oemar. 2008. Kurikulum dan Pembelajaran. Jakarta: Sinar Grafika.

Kartodirdjo, Sartono. 1993. Pendekatan Ilmu Sosial dalam Metodologi Sejarah. Jakarta: Gramedia Pustaka Utama.

Kochhar, S.K. 2008. Pembelajaran Sejarah: Teaching History. Diterjemahkan oleh Purwanta dan Yovita Hardiwati. Jakarta: Gramedia Widiasarana Indonesia.

Nadlir. 2014. Urgensi Pembelajaran Berbasis Kearifan Lokal. Jurnal Pendidikan Agama Islam. 2(2): 299-330.

Rasyid, Hatamar. 2015. Nilai-Nilai Kearifan Lokal dalam Pengembangan Pendidikan Karakter di Era Global. Jurnal Edugama. 1(1): 1-31.

Sutopo, H.B. 2006. Metodologi Penelitian Kualitatif: Dasar Teori dan Terapannya dalam Penelitian (Edisi Kedua). Surakarta: Universitas Sebelas Maret Press.

Suradi. 2017. Pembentukan Karakter Siswa melalui Penerapan Disiplin Tatat Terbit Sekolah. Briliant: Jurnal Riset dan Konseptual. 2(4): 522-533.

Wahab, A.A. 1996. Politik Pendidikan dan Pendidikan Politik: Model Pendidikan Kewarganegaraan Indonesia Menuju Warganegara Global: Pidato Pengukuhan Guru Besar Tetap PPKN, IPS, IKIP. Bandung.

Widja, I Gde. 1989. Dasar-Dasar Pengembangan Srategi Serta Metode Pengajaran Sejarah. Jakarta: Depdikbud. 